\title{
Preface: The European Union and the Rule of Law
}

\section{Gisela Stuart}

Wittgenstein thought that the 'aim of philosophy is to show the fly the way out of the fly-bottle'. The Lisbon Treaty and its precursor, the Constitutional Treaty, was to make the European Union more effective, accountable and transparent, as well as bringing it closer to the people. After years teaching EU law, attending Council of Ministers' meetings and having been one of the 13 people who drafted the Constitutional Treaty - I, just like Wittgenstein's fly - am still in need of help. Trying to understand the entirety and complexity of the workings, rules and institutions of what we call Europe makes getting out of the fly-bottle look like child's play. What's gone wrong?

For a start don't call it Europe. It is the European Union, or the Union for short. Europe is a geographic entity which stretches from Ireland in the west to the Urals in the east. It is a historic entity which certainly includes the capital city of the Eastern Roman Empire, known today as Istanbul. The Union on the other hand is a post-World War II construct of currently 27 nation states.

With the Lisbon Treaty the Union is said to have given up its ambition for wider and deeper integration and accepted that it is made up of sovereign Member States; it has no intentions of moving towards a federal structure. Lisbon has given greater powers to the European Parliament, transferred whole swathes of areas from unanimity to qualified majority, done away with the Pillar structure which protected competences, and created new institutions like the Diplomatic Service and a Foreign Representative. One is left to wonder just what else they could they have done had they intended to 'widen and deepen'.

The Union's individual components can claim democratic legitimacy, the Union itself cannot. The members of the European Parliament are elected in the Member States. They campaign on national party tickets. Once elected, their political groups in the European Parliament bear little resemblance to the national party they came from. Whether left or right, what 
matters much more is whether their party is in government back home or not. Believe me, as a Labour minister in the Blair administration, I constantly had to face the British Labour MEPs voting against us. The Council of Ministers is composed of democratically elected ministers of the Member States, but they change so frequently that the collective memory of the institution remains with Brussels bureaucrats. Until the permanent representations in Brussels become answerable to national parliaments, the deals and trade-offs will forever remain secret and unaccountable. The Commissioners are appointed by democratic Member States, but once they take up office they vow their allegiance to the institution they serve. The European Court of Justice does much more than applying and interpreting the law. Part of its institutional remit is to 'further European integration'. Its interpretations and judicial developments cannot be corrected by further primary legislation as is the case in nation states. Democratic checks and balances are missing in the Union. No wonder that after Lisbon the Union is even more remote from the people than it was before.

Aristotle tells us in his Metaphysics that 'the whole is greater than the sum of its parts'. In the case of the Union it's something else. To some this is a great achievement; a supranational organisation which we have not seen before. To others it is a 21st-century form of an empire that becomes consumed by perpetuating self interest in the constant struggle for survival. It is probably a bit of both, but for me democracy is a space within which political discourse can take place, and at regular intervals those who govern can - at will - be removed by those who are governed. If the European Union wants to survive it has to anchor itself in the democratic institutions of the nation state, not try to replace them.

Gisela Stuart, Member of Parliament for Edgbaston Member of the former Convention on the Future of Europe 